\title{
Marcin Gubata
}

\author{
Wyższa Szkoła Bankowa w Gdańsku
}

\section{KOMISJE PRAWA W PAŃSTWACH WSPÓLNOTY NARODÓW. ZARYS ZAGADNIEŃ USTROJOWYCH}

\section{WSTĘP}

Celem opracowania jest przedstawienie w zarysie zagadnień ustrojowych związanych z komisjami prawa ${ }^{1}$. Komisje są instytucjami stanowiącymi wyraz instytucjonalnego podejścia do reformy prawa, wywodzącymi się z obszaru kultury anglosaskiej, rozpowszechnionymi w szczególności w państwach Wspólnoty Narodów (Commonwealth of Nations) $)^{2}$.

1 Na potrzeby opracowania przyjąłem dla opisywanych instytucji nazwę zbiorczą „komisja prawa”. Niemniej należy zwrócić uwagę na różnice w nazewnictwie tego rodzaju instytucji. W niektórych przypadkach nazwą tą jest law commission (czyli właśnie komisja prawa - tak jest m.in. w Anglii i Walii, Nowej Zelandii oraz Bangladeszu; z uwagi na to, że instytucja brytyjska jest w mojej ocenie punktem odniesienia dla innych komisji, uznałem, że na potrzeby opracowania to określenie będzie adekwatne), występują też jednak nazwy wskazujące wprost na reformatorską funkcję: law reform commission (tak m.in. w Australii, Ghanie, Gujanie, Kenii, Lesotho, Nigerii i RPA, na Dominice oraz na Fidżi), law reform and revision commission (Bahamy), law development commission (Zambia), law reform and development commission (Namibia), constitutional and law reform commission (Papua Nowa Gwinea). Nieco odmienne nazewnictwo zastosowano w Pakistanie (law and justice commission).

2 Commonwealth of Nations - organizacja międzynarodowa, zrzeszająca (według stanu na dzień 20 kwietnia 2019 r.) 53 państwa, zamieszkane łącznie przez ok. 
W artykule przedstawiam ustalenia dotyczące sytuacji ustrojowej komisji prawa; wskazuję sposoby umocowania komisji prawa, podkreślam istotną cechę komisji, jaką jest ich niezależność, a także omawiam ich główne zadania.

Pomimo tego, że komisje prawa działają w ramach wielu systemów prawa, można stwierdzić, że charakteryzują się one zbieżnymi właściwościami, pozwalającymi na mówienie o nich jako o jednej (choć nie jednolitej) grupie instytucji. Instytucje, które powstały w państwach Wspólnoty Narodów ${ }^{3}$, co do zasady nawiązują w swej konstrukcji do bry-

2,4 miliarda ludzi. Korzeniami organizacja ta sięga czasów Imperium Brytyjskiego, a jej obecny kształt został ustalony w kwietniu 1949 r., kiedy doszło do spotkania szefów rządów Wielkiej Brytanii, dominiów, Indii, Pakistanu i Cejlonu: „Uzgodniono wówczas, iż republikańskie Indie pozostaną we Wspólnocie Narodów [...]. Wypracowana w kwietniu 1949 r. formuła stała się nową podstawą przyszłego funkcjonowania Wspólnoty, która straciła przymiotnik «brytyjska» z nazwy, ale dawała republikom możliwość uczestnictwa w jej pracach za niezbyt wygórowaną cenę uznania monarchy brytyjskiego za symbol i głowę organizacji” (A. Polus, Commonwealth na arenie międzynarodowej, Wrocław 2009, s. 33). Aktualnie wśród członków Wspólnoty Narodów jedynie Rwanda i Mozambik nie pozostawały w relacjach kolonialnych bądź ustrojowych ze Zjednoczonym Królestwem (Mozambik został członkiem Wspólnoty w 1995 r., a Rwanda - w 2009 r.). W starszej literaturze tę instytucję polityczną nazywano także Brytyjską Rzeczpospolitą Narodów (np. M. STARzEwsKi, Ustrój dominionów i charakter Brytyjskiej Rzeczpospolitej Narodów, Kraków 1939).

3 Już w latach 60. XX w. komisje powołano w Ghanie, na Sri Lance i na Trynidadzie i Tobago, w latach 70. - w Kanadzie, Australii, RPA, na Bahamach, w Papui Nowej Gwinei, w Sierra Leone, na Fidżi, w Nigerii i Pakistanie, w latach 80. - w Tanzanii, Kenii i Nowej Zelandii, w latach 90. - w Ugandzie, Namibii, na Dominice, w Lesotho, Malawi, na Wyspach Salomona, w Bangladeszu i Zambii, w pierwszej dekadzie po roku 2000 - w Suazi, na Samoa, Mauritiusie, Tonga i Vanuatu, po roku 2010 - w Rwandzie i Gujanie. Należy też zwrócić uwagę, że w Kanadzie i Australii funkcjonowały instytucje zajmujące się reformą prawa (law reform agencies) na poziomie prowincji i stanów (w Kanadzie - w prowincjach Ontario, Alberta, Kolumbia Brytyjska, Saskatchewan, Nowa Szkocja, Manitoba, Wyspa Księcia Edwarda; w Australii - w stanach: Nowa Południowa Walia, Australia Zachodnia, Australia Południowa, Queensland, Wiktoria, Tasmania, a także w Australijskim Terytorium Stołecznym). W 2006 r. doszło do zamrożenia działania komisji prawa w Kanadzie na poziomie centralnym. Szerzej o rozwoju i funkcjonowaniu komisji w Australii i Kanadzie por. M. Kirby, Forty years of the Alberta Law Reform Institute - past, present, future, "Alberta Law Review» 46.3/2009, s. 831 i n.; J. BARnEs, On the ground and tap-law reform, Australian style, 
tyjskich komisji prawa, przy czym uwzględniają one zarówno specyfikę uwarunkowań prawnych w danym państwie, jak i potrzeby, które mają związek z okolicznościami społecznymi, politycznymi, historycznymi i kulturowymi.

Opracowanie zostało oparte w przeważającej mierze na wynikach dokonanej przeze mnie analizy aktów normatywnych stanowiących podstawę prawną funkcjonowania komisji w poszczególnych państwach Wspólnoty Narodów.

\section{UMOCOWANIE PRAWNE KOMISJI PRAWA}

W państwach Wspólnoty Narodów prawodawcy przeważnie odwołali się do metody polegającej na wyraźnym, pozytywnym unormowaniu zagadnień związanych z funkcjonowaniem komisji w akcie zajmującym wysoką pozycję w hierarchii źródeł prawa. Dlatego też podstawą prawną działania komisji jest co do zasady ustawa $(a c t)^{4}$, poświęcona jedynie zagadnieniom związanym z komisją ${ }^{5}$. Na tle tej reguły należy wyróżnić kilka wyjątków.

Po pierwsze, istnieje przypadek regulacji, która kreuje komisję prawa na poziomie konstytucyjnym. Chodzi mianowicie o komisję działającą w Malawi. Konstytucja tego państwa poświęca rozdział XII w całości działaniu komisji prawa. W przepisach konstytucyjnych przesądzono powołanie komisji (i wymóg uszczegółowienia zasad jej działania na poziomie ustawowym) oraz ogólny zakres jej zadań, skład komisji,

«The Theory and Practice of Legislation» 6.2/2018, s. 193 i n.; M. Moore, The past, present and future of law reform in Canada, "The Theory and Practice of Legislation» $6.2 / 2018$, s. 226 i n.

4 Komisja funkcjonująca w Pakistanie została utworzona na podstawie aktu władzy wykonawczej (ordinance), który miał moc prawną równą ustawie.

5 Komisja w Irlandii Północnej działała na podstawie The Justice (Northern Ireland) Act z 2002 r., który reguluje sprawy organizacji wymiaru sprawiedliwości w tym państwie. 
przesłanki usunięcia członka komisji ze stanowiska, kompetencje komisji, wyartykułowanie zasady niezależności komisji ${ }^{6}$.

Po drugie, istnieje komisja, która nie jest umocowana ustawowo, ale której funkcjonowanie zapewniają delegowane akty władzy wykonawczej. Mowa tu o komisji prawa w Indiach; w przypadku tej instytucji jej byt prawny jest „odnawiany” na mocy rozporządzeń ministra właściwego do spraw sprawiedliwości (ministry of law and justice order). Akty te określają czas, na który jest powołana komisja, a także zawierają unormowania odpowiadające swym zakresem ustawom kreującym komisje w innych państwach (łącznie z określeniem zadań komisji i ich składu) ${ }^{7}$.

Po trzecie, istnieją też komisje prawa, które nie znajdują ścisłego uregulowania prawnego. Chodzi o grupę komisji funkcjonujących w oparciu między innymi o instytucje szkolnictwa wyższego i nauki (university-based partnership models) ${ }^{8}$. W tej grupie można wskazać komisje, których byt ma swoje źródło w porozumieniach międzyinstytucjonalnych. Przykładem może być Instytut Reformy Prawa w Tasmanii (Tasmania Law Reform Institute), który powstał na mocy porozumienia zawartego między rządem Tasmanii, Uniwersytetem Tasmańskim i jednym $z$ towarzystw naukowych (Law Society) ${ }^{9}$. Nieco innym przypadkiem jest komisja działająca w Singapurze (Singapore Law Reform Committee); funkcjonuje ona w ramach Singapurskiej Akademii Prawa (Singapore Academy of Law) ${ }^{10}$. Podstawą funkcjonowania tej komisji

\footnotetext{
6 Sekcje 132-136.

7 Od 1955 r. powołano w Indiach 21 komisji prawa. Co do zasady kadencja tych
} organów wynosiła trzy lata (zdarzały się krótsze okresy - ósma komisja działała w latach 1977-1979, a także dłuższe - dziesiąta komisja funkcjonowała w latach 1981-1985).

8 Por. K. WARner, Lessons from a Small University-based Law Reform Body in Australia, [w:] Reforming Law Reform. Perspectives from Hong Kong and Beyond, red. L. NG, M. Tilbury, S. Young, Hong Kong 2014, s. 116.

Ibidem, s. 117. Do innych instytucji tego typu należy zaliczyć kanadyjską komisję prawa w Ontario (Law Commission of Ontario), komisję w Australijskim Terytorium Stołecznym (Australian Capital Territory Law Reform Advisory Council) oraz w Południowej Australii (South Australian Law Reform Institute).

10 Akademia jest agencją, działającą na podstawie The Singapore Academy of Law Act z 1988 r. Ustawa ta stanowi m.in., że do zadań Akademii należy promocja i utrzymanie wysokiego poziomu wykonywania profesji prawniczych (high standards of 
jest z kolei przepis ustawy normującej status Akademii, przewidujący możliwość powoływania przez senat ciał kolegialnych (committees and boards). Co prawda komisja jest w ten pośredni sposób umocowana ustawowo, jednak brak jest aktu tej rangi, który konstytuowałby ją i wyznaczał reguły funkcjonowania.

Ujmując tę kwestię od strony zakresu regulacji, należałoby uznać, że co do zasady akty prawne odnoszące się do komisji mają charakter kompleksowy. Ustawy regulują przeważnie następujące kwestie: powołanie komisji prawa, skład, zadania, strukturę organizacyjną, sprawozdawczość, wynagrodzenie członków komisji. Do wyjątków należą sytuacje, w których ustawy regulujące sprawy komisji odsyłają do innych ustaw normujących zasady funkcjonowania instytucji publicznych; $\mathrm{z}$ takim przypadkiem mamy do czynienia w Nowej Zelandii ${ }^{11}$.

Jak wynika z powyższego, komisje prawa są instytucjami o, co do zasady, trwałych i kompleksowych podstawach prawnych. Świadczy to, jak można sądzić, o zamiarze prawodawców, by komisje nie były ustrojowymi efemerydami, ale by stale i niezależnie od aktualnych trendów politycznych funkcjonowały jako części składowe ustroju państwowego.

\section{NieZAleżNośĆ KOMISJI PRAWA}

Na pojęcie niezależności komisji prawa składa się kilka elementów ${ }^{12}$. Najpierw należałoby wskazać na niezależność w znaczeniu negatywnym, a zatem na odseparowanie od innych władz publicznych, w szczególności od władzy ustawodawczej i wykonawczej. Komisja nie ma przydanych

conduct and learning of the members of the legal profession), promocja wiedzy o prawie i systemie prawa, promocja badań naukowych w obszarze prawa, a także, co istotne z punktu widzenia omawianego zagadnienia, promocja reform i rozwoju prawa.

${ }^{11}$ Ustawa odsyła częściowo do aktu ogólnie regulującego funkcjonowanie instytucji publicznych w tym państwie - The Crown Entities Act z 2004 r.

12 W piśmiennictwie wskazuje się, że także (omówiony wcześniej) sposób umocowania prawnego (co do zasady ustawowego) jest elementem współkreującym niezależność komisji prawa - por. M. ARden, Law and Law Reform: Are We Ready for the Twenty-First Century?, «The Liverpool Law Review» 20.2/1998, s. 163. 
kompetencji do ustanawiania prawa ani nie jest elementem instytucjonalnym, którego zadaniem byłoby egzekwowanie prawa. Komisja jest ciałem profesjonalnym (eksperckim), apolitycznym, niewładczym, ma za zadanie analizować skutki obowiązywania prawa i oceniać jego jakość, a także proponować rozwiązania o charakterze systemowym. Częściowo dałoby się obdzielić tymi zadaniami zarówno legislatywę, jak i egzekutywę, niemniej w sumie zakres działania komisji prawa ma charakter wyjątkowy. Komisji prawa nie da się zakwalifikować do żadnej z „klasycznych” władz.

Brak związania komisji z egzekutywą jest uzasadniony zasadniczą wartością tak rozumianej (instytucjonalnej) niezależności: reforma prawa ma większe szanse powodzenia (i większą szansę na zaakceptowanie przez różne środowiska i grupy interesu), jeśli jest przygotowywana przez instytucję niepowiązaną bezpośrednio z rządem (zwykle realizującym określoną „linię polityczną”, niekoniecznie akceptowaną przez większość) $)^{13}$. Powyższe nie oznacza wszelako, że władza wykonawcza nie ma wpływu na funkcjonowanie komisji prawa. Wpływ ten można zidentyfikować $\mathrm{w}$ trzech obszarach. Po pierwsze - w zakresie kształtowania substratu osobowego komisji prawa. Członków komisji co do zasady powołują organy wchodzące w skład władzy wykonawczej; są to zarówno głowy państw (Tanzania, Fidżi, Gujana, Lesotho, Namibia, Nigeria, RPA, Rwanda), rząd (Bangladesz), ministrowie właściwi w sprawach wymiaru sprawiedliwości (Anglia i Walia, Vanuatu, Wyspy Salomona, Papua Nowa Gwinea, Dominika, Malta), jak i gubernatorzy generalni (Australia, Bahamy). Po drugie, władza wykonawcza zapewnia funkcjonowanie komisji w aspekcie finansowym i organizacyjnym. Dla przykładu można przywołać brytyjską ustawę wskazującą, że koszty funkcjonowania komisji, w tym koszty wynagrodzeń członków komisji

13 Zauważa się, że samo powołanie komisji prawa zostało spowodowane tym, iż reforma prawa nie powinna być pozostawiona wyłącznie agendom rządowym. Zaangażowanie rządu w bieżące sprawy skutkuje brakiem możliwości poświęcenia uwagi systematycznej zmianie. Tym samym reforma prawa stanowionego (law reform of the statute book) nigdy nie była priorytetem żadnej rządowej instytucji - por. Statute law repeals at the Law Commission. A review of our work 1965 to 2010, https://www.lawcom. gov.uk/our-work/statute-law-repeals/ (dostęp: 20 kwietnia 2019 r.). 
i personelu, będą pokrywane ze środków zapewnionych przez organy władzy publicznej (w przypadku Anglii i Walii - przez legislatywę, w przypadku Szkocji - przez ministrów) ${ }^{14}$. Po trzecie, przepisy regulujące działanie komisji prawa ustanawiają obowiązek współdziałania z władzą wykonawczą, co umożliwia przekształcanie postulatów zmian prawa w projekty aktów prawnych i nadawanie im biegu legislacyjnego. Innymi słowy, egzekutywa jest niejako pośrednikiem między komisją prawa a legislatywą. Ustawa brytyjska nakłada na egzekutywę obowiązek przedkładania Parlamentowi programów reform prawa oraz projektów (propozycji) sformułowanych przez komisje $e^{15}$. Z drugiej strony, władza wykonawcza jest zobligowana do sprawozdawczości w zakresie stopnia implementacji propozycji przedkładanych przez komisje.

Drugim elementem niezależności jest kwestia zasobu intelektualnego. Skład komisji musi być tak skomponowany, aby gwarantować możliwie najwyższą jakość prac tego organu, przy czym jest istotne, by komisja nie była zobligowana do ciągłego sięgania po zasoby administracji publicznej. Wiąże się to z koniecznością właściwego doboru kadr (zarówno członków komisji, jak i aparatu pomocniczego). Do charakterystycznych cech komisji prawa należy specyficzne ukształtowanie substratu osobowego tych instytucji. Trzeba tu wspomnieć o dwóch podstawowych zagadnieniach, mianowicie o liczebności komisji oraz o merytorycznych wymogach dotyczących członków komisji.

W odniesieniu do pierwszego zagadnienia należy zauważyć, że komisje są ciałami o relatywnie skromnym składzie. Organy te liczą najczęściej po kilka osób (przykładowo - w Bangladeszu jest to 3 członków ${ }^{16}$, w Nigerii - 4 członków, w Anglii i Walii, w Vanuatu i na Wyspach Salomona jest to 5 członków, w Nowej Zelandii - od 3 do 6, w Gujanie - od 3 do 7, w Australii i Kenii - 7, w Tanzanii - od 5 do 7, na Sri Lance - 8, w Lesotho - nie więcej niż 8 członków, w Namibii - nie więcej

14 Sekcja 5 The Law Commission Act.

15 Sekcja 3 ust. 2 The Law Commission Act.

16 Dodatkowo The Law Commission Act z 1996 r. przewiduje możliwość powołania honorowych członków komisji. 
niż 9 członków) lub 10, ewentualnie kilkanaście osób (w Pakistanie - 10 członków ${ }^{17}$, na Mauritiusie - 11 członków).

Co do zasady skład osobowy jest określony w akcie prawnym kreującym daną komisję, przy czym istnieją również i takie regulacje, które przewidują kompetencję określonych organów państwa do ustalania liczby członków komisji (np. na Dominice skład komisji to co najmniej trzy osoby powołane przez ministra sprawiedliwości). Może zastanawiać, jak ma się skromny liczbowo skład do rozbudowanych zadań komisji, które mają przecież charakter horyzontalny i systemowy. Otóż istotne jest to, że sama komisja jest wspierana przez aparat pomocniczy, który umożliwia jej wykonywanie złożonych zadań, a ponadto korzysta ona $z$ pracy ekspertów zewnętrznych ${ }^{18}$. Należy przy tym dostrzec, że akty prawne w zasadzie poprzestają na uregulowaniu możliwości zatrudniania wykwalifikowanego personelu do pomocy członkom komisji, w tym sekretarza komisji ${ }^{19}$.

Cecha komisji prawa, jaką jest jej profesjonalizm, ujawnia się w wyniku analizy przepisów regulujących wymogi kwalifikacyjne jej członków. W tym zakresie zwraca uwagę zapobiegliwość prawodawców, by ukształtować owe wymogi w sposób gwarantujący fachowy skład komisji, a przez to - zapewnić jej działanie na najwyższym merytorycznym poziomie. Wyraża się to przede wszystkim w unormowaniach wskazujących na wymóg wykształcenia i doświadczenia zawodowego członków komisji. Można w tym zakresie mówić o kilku modelach. Pierwszy z nich opiera się na członkostwie łączącym się z pełnieniem innej funkcji publicznej. Najczęściej są to funkcje w systemie organów wymiaru sprawiedliwości i ochrony prawnej (np. w Namibii członkami komisji są m.in. osoby pełniące funkcje ombudsmana oraz prokuratora generalnego, w RPA przewodniczącym komisji jest sędzia

\footnotetext{
17 Istnieje możliwość powołania dodatkowych członków komisji.

18 Por. M. Partington, Law Reform: The UK Experience, [w:] Reforming Law Reform..., s. 73.

19 Szczególnym rozwiązaniem jest w tym zakresie regulacja normująca działanie komisji w Rwandzie; przewiduje ona istnienie następujących organów Rwandyjskiej Komisji Reformy Prawa: rady komisarzy (Council of Commissioners), biura komisji oraz rady doradczej (Advisory Council).
} 
Sądu Konstytucyjnego, w Anglii i Wali - przewodniczącym jest sędzia jednego z sądów: High Court of Justice albo Court of Appeal). Drugi model opiera się na bardziej elastycznym opisie wymogów kwalifikacyjnych członków komisji, ale wciąż rezerwuje członkostwo w niej dla osób, które legitymują się wyróżniającym doświadczeniem w zawodach związanych ze stosowaniem prawa (lub jego nauczaniem). Chodzi o zawodowe doświadczenie prawnicze w sądownictwie (Anglia i Walia, Bahamy, Uganda), w wykonywaniu innego zawodu prawniczego (Dominika, Mauritius, Nowa Zelandia) lub w pracy naukowej na uczelni (Bahamy, Dominika, Gujana). Innym sposobem opisu wymagań jest ogólne wskazanie, że osoba pełniąca funkcję członka komisji powinna posiadać odpowiednią wiedzę i doświadczenie w zakresie prawa (tak w Rwandzie czy w Vanuatu). Tylko wyjątkowo mamy do czynienia $\mathrm{z}$ regulacjami, które w zakresie wymogów kwalifikacyjnych odsyłają do innych przepisów, normujących w sposób uniwersalny kwestie warunków obejmowania funkcji publicznych (taka sytuacja odnosi się do komisji w Bangladeszu i na Malcie).

Można sobie pozwolić na konstatację, że prawodawcy w poszczególnych państwach położyli duży nacisk na zapewnienie wysokiego poziomu merytorycznego komisji w zakresie osobowym, przy czym wyraźnym trendem jest powierzanie pełnienia funkcji w komisjach osobom, które zajmują (bądź zajmowały) stanowiska sędziowskie. Jest to bez wątpienia votum zaufania dla tej grupy zawodowej, a jednocześnie podkreślenie, że sędziowie - dzięki swoim kwalifikacjom, wiedzy i doświadczeniu „systemowemu” - mogą z powodzeniem wykonywać zadania, które nie polegają na stosowaniu prawa, ale na jego kompleksowym i systematycznym przeglądzie.

\section{ZADANIA KOMISJI PRAWA}

W zakresie zadań komisji prawa należy zwrócić uwagę na trzy zasadnicze zagadnienia, tj. uniwersalność tych zadań, ich treść oraz brak władczych kompetencji komisji prawa. 
Uniwersalność zadań komisji prawa polega na tym, że zakres działania tych instytucji nie jest właściwie ograniczony do jakiejkolwiek dziedziny (gałęzi) prawa, wobec czego komisje mogą zajmować się niemal każdym elementem systemu prawnego. Wynika to z tego, że ustawy kreujące komisje nie zawężają perspektywy działania tych instytucji, a co więcej, niektóre akty prawne wprost wskazują, że komisja obejmuje swoim zakresem całe prawo obowiązujące $\mathrm{w}$ danym państwie (all the law - tak m.in. w Anglii i Walii, na Bahamach, Fidżi, w Kenii, Sierra Leone, Tanzanii). Do wyjątków należałoby zaliczyć regulacje, które wprost wskazują na zakres spraw, jakimi może zajmować się komisja prawa ${ }^{20}$.

W zakresie treści zadań należy wskazać dwa poziomy unormowań. Pierwszym poziomem jest określenie zakresu zadań komisji prawa, czyli - z jednej strony granic odpowiedzialności tych instytucji, a z drugiej - wyznacznika ich roli w systemie ustrojowym poszczególnych państw. W tym względzie należy zauważyć, że częścią wspólną zadań komisji prawa jest działanie w celu dokonywania przeglądu prawa. Dokonywanie przeglądu (review) urasta do miana podstawowej, wręcz „istotowej” właściwości tych instytucji. W zróżnicowanych co do niuansów, lecz zbieżnych co do sensu formułach zadanie to kształtuje profil funkcjonalny komisji prawa między innymi w Tanzanii, Vanuatu, Anglii i Walii (oraz Szkocji), Nowej Zelandii, Lesotho, Malawi, Mauritiusie, Sierra Leone, Rwandzie oraz na Fidżi. Co ważne, przeglądy prawa mają być podejmowane w prawnie zdeterminowanych celach. Wśród celów tych można zidentyfikować przede wszystkim takie, które odnoszą się do ogólnego polepszenia stanu regulacji prawnych. Mowa tu głównie o systematycznej poprawie systemu prawa, o jego rozwoju, modernizacji i reformie prawa, konsolidacji prawa, a także jego kodyfikacji ${ }^{21}$. Zwraca uwagę to, że cele są wspólne dużej części komisji prawa, choć występują w różnych kombinacjach, a jednocześnie są funkcjonalnie ze sobą

20 Należałoby tu wskazać na komisję prawa w Papui Nowej Gwinei, która ma zajmować się m.in. analizą funkcjonowania przepisów konstytucyjnych.

${ }_{21}$ Ustawy w tym względzie posługują się takimi sformułowaniami, jak: development, systematic development, improvement, systematic improvment, modernization. 
powiązane ${ }^{22}$. Wymaga też podkreślenia nacisk na systematyczność działania, a zatem stałość w dążeniu do realizacji głównych zadań komisji.

Drugi poziom regulacji to unormowania określające szczegółowe zadania komisji prawa, wpisujące się w wyżej wskazany ogólny zakres. Pierwsze zadanie polega na identyfikowaniu obszarów prawa, które należy poddać badaniu, i na proponowaniu reformy tych obszarów. Ustawy regulujące komisje prawa nie definiują pojęcia „reforma”, dlatego jego treść była rozwijana na gruncie praktyki działania tych instytucji ${ }^{23}$. Można spróbować opisać to zadanie, odwołując się do zasadniczych faz, które składają się na działanie reformatorskie, tj. do inicjowania prac i ich formalnego prowadzenia. Trzeba przy tym zaznaczyć, że przepisy statuujące komisje nie zawierają szczegółowych unormowań proceduralnych dotyczących działań reformatorskich. Kwestie te pozostają w sferze praktyki działania instytucji publicznych zajmujących się legislacją, choć należy także odnotować przypadek ujęcia ich w ramy szczególnego aktu prawnego (porozumienia międzyinstytucjonalnego) ${ }^{24}$.

22 Pojęcia „rozwój” (development) i „reforma prawa” występują w związku ze sobą, stanowiąc niejako podstawowy składnik, z którego rekonstruowany jest główny cel działania komisji (tak jest w przypadku komisji prawa w Ugandzie, Namibii, Tanzanii, RPA, Lesotho, Malawi, Fidżi, Gujanie, Nigerii, Rwandzie, Trynidadzie i Tobago oraz na Wyspach Salomona).

23 Sprawa jest zresztą kontrowersyjna, ponieważ nie ma zgody co do desygnatów tego pojęcia; por. S.W. STARK, The Work of the British Law Commissions. Law Reform... Now?, Oxford-Portland 2017, s. 247.

24 Mowa o porozumieniu zawartym między rządem, reprezentowanym przez Lorda Kanclerza, i komisją prawa w Anglii i Walii z marca 2010 r. (Protocol between the Lord Chancellor (on behalf of the government) and the Law Commission). Dokument reguluje współdziałanie między administracją rządową (Government departments) i komisją prawa w celu przeprowadzania reform prawa w możliwie najefektywniejszy sposób. Akt normuje zagadnienia proceduralne na wszystkich etapach prac komisji nad projektami reformy prawa, zaznacza jednak wyraźnie, że nie obejmuje działań związanych z konsolidacją prawa i jego oczyszczeniem. Co godne podkreślenia, porozumienie niejako uzupełnia ustawę o komisji prawa, wskazując kryteria, jakimi komisja powinna się kierować przy wyborze projektów (m.in. stopień, w jakim prawo w danym obszarze wymaga poprawy, korzyści płynące z planowanej reformy, to, czy komisja prawa jest najwłaściwszą instytucją do zaprojektowania reformy, to, czy komisja dysponuje doświadczeniem w danej sferze, stopień wsparcia zapewnionego 
Naprzód należy zwrócić uwagę na selekcjonowanie zagadnień, którymi ma się zająć komisja i wobec których ma podjąć wysiłek reformatorski. Z uwagi na przywołany wyżej uniwersalizm zadań komisji, także i w zakresie reformy prawa ustawy nie rozstrzygają tego, którymi obszarami systemu prawa mają się zajmować omawiane instytucje. Nie określają też kryteriów, którymi mogłyby się kierować komisje przy wyborze materii. Inspiracja w tym względzie może wypływać z trzech źródeł: od samej komisji, od rządu oraz od innych podmiotów (w szczególności instytucji i organizacji wyspecjalizowanych w zakresie badań nad prawem) $)^{25}$. W każdym razie decyzja co do priorytetyzacji działań komisji należy do niej samej ${ }^{26}$. Co ważne, sygnalizowany już kształt instytucjonalny komisji nie pozwala jej na działanie w wielu obszarach jednocześnie; stąd reforma prawa, choć determinowana normatywnym nakazem podejmowania czynności odnoszących się do całego systemu prawnego, siłą rzeczy ma charakter fragmentaryczny.

Po wyborze materii, która ma być poddana badaniu, następują prace w komisji uwieńczone dokumentem roboczym (working paper/consultation paper/discussion paper $)^{27}$. W dokumencie tym zawiera się wstępne wyniki studiów przeprowadzonych przez komisję, w tym rekomendacje działań legislacyjnych, choć już na tym etapie może dojść do przedłożenia projektu aktu prawnego ${ }^{28}$. Dokument jest kolejno poddawany konsultacjom, które mają szeroki charakter i - dzięki wykorzystaniu różnych kanałów komunikacyjnych - są nakierowane na uzyskanie opinii pochodzących nie tylko od ekspertów w danej dziedzinie. Po etapie konsultacji ma miejsce opracowanie raportu, któremu może to-

przez agendy rządowe, priorytetowość projektu) - por. https://s3-eu-west-2.amazonaws. com/lawcom-prod-storage-11jsxou24uy7q/uploads/2015/06/lc321_Protocol_web.pdf (dostęp: 20 kwietnia 2019 r.).

25 Por. S.W. STARK, op. cit., s. 53.

26 Zdarza się, że egzekutywa korzysta z zasobów komisji dla opracowania reformy określonego wycinka systemu prawa (przykładem może być działanie australijskiej komisji prawa w zakresie przygotowania reformy prawa rodzinnego - por. https:// www.alrc.gov.au/inquiries/family-law-system; dostęp: 20 kwietnia 2019 r.).

27 S.W. STARK, op. cit., s. 41.

${ }_{28}$ Tak jest np. w RPA - por. http://www.justice.gov.za/salrc/dpapers.htm (dostęp: 20 kwietnia 2019 r.). 
warzyszyć projekt aktu prawnego. W piśmiennictwie dostrzega się dużą wartość raportu wzbogaconego o projekt regulacji i podkreśla się, że jest to przejaw „praktyczności” działania komisji prawa ${ }^{29}$.

Drugim zadaniem jest porządkowanie systemu prawa. Należy przez to rozumieć przede wszystkim działania zmierzające do usuwania z systemu prawa regulacji zbędnych (repeal) oraz konsolidowanie aktów prawnych (consolidate). Trzeba podkreślić, że jedną z przesłanek powołania komisji była obserwacja dotycząca wolumenu treści prawnych obecnych w systemie prawa, a także ich aktualności. Zbyt obszerny wolumen norm nie sprzyja spoistości prawa i jego funkcjonalności, stąd jednym z elementów szeroko rozumianych działań naprawczych w dziedzinie legislacji powinno być jego ograniczenie. Temu też miałoby służyć działanie polegające na aktualizowaniu prawa, czyli eliminowaniu z systemu prawnego treści przestarzałych i niepotrzebnych. W sumie czynności w tym zakresie służą temu, by prawo stało się bardziej „poręczne” czy też „przyjazne użytkownikowi” (user-friendly) ${ }^{30}$. Należy wszelako zwrócić uwagę na właściwość tego rodzaju działań - otóż nie mają one charakteru zasadniczych reform prawa, nie naruszają podstawowych struktur normatywnych w określonych dziedzinach, ale jedynie mają na celu „oczyszczenie” systemu prawa. Zadania tego rodzaju są wpisane w katalog kompetencji wielu komisji prawa (oprócz Anglii i Walii dotyczy to m.in. komisji w Australii, na Bahamach, w Bangladeszu, na Fidżi, w Gujanie, Namibii, Nigerii, Papui Nowej Gwinei i Rwandzie). W praktyce działania „oczyszczające” przyjmują postać projektów aktów prawnych będących swoistym konglomeratem propozycji legislacyjnych, często dotyczących różnorodnych spraw, nakierowanych na uchylenie całych aktów prawnych lub ich części (tzw. ustawy uchylające - repeal acts) ${ }^{31}$.

\footnotetext{
29 S.W. STARK, op. cit., s. 42.

30 Ibidem, s. 43.

31 Dla przykładu w Wielkiej Brytanii od początku działania Law Commission uchylono ponad 3000 całych aktów prawnych na skutek wejścia w życia ustaw uchylających (w Wielkiej Brytanii przyjmują one nazwę Statute Law (Repeals) Act). Wysiłek związany z „oczyszczaniem” systemu prawa brytyjskiego został wszelako podjęty na długo przed powołaniem komisji. W latach 1856-1952 uchwalono 37 ustaw tego rodzaju (w tym czasie nosiły one przeważnie nazwę Statute Law Revision Bill). Po ustanowieniu
} 
Z działaniami „porządkującymi” jest związana również aktywność komisji na polu konsolidowania prawa. Także i w tym przypadku zwraca się uwagę na znaczenie tych działań dla użyteczności prawa ${ }^{32}$. Konsolidacja powinna być przy tym rozumiana jako zmniejszanie liczby obowiązujących ustaw, ale niekoniecznie - jako usuwanie norm prawnych z systemu prawa. Nie chodzi tu o ograniczanie zakresu regulacji, ale o legislacyjną zmianę polegającą na skupianiu przepisów dotyczących zbieżnych materii w mniejszej liczbie aktów normatywnych. Do ciekawych właściwości konsolidacji należy możliwość dokonywania dodatkowych czynności wobec materiału normatywnego; w tym zakresie wymienia się usuwanie zbędnych (przestarzałych) treści normatywnych,

komisji pierwszy tego typu akt został uchwalony w 1969 r., jak dotąd ostatni - w 2013 r. Ta „najświeższa” ustawa przewidywała zniesienie 817 aktów prawnych w całości i 50 w części - por. D. Jones, The Law Commission and the implementation of law reform, "Amicus Curiae» 94/2013, s. 3. Zwraca uwagę także szczególna struktura tego rodzaju aktów. Oprócz wstępu określającego cel ustawy akty te składają się z zestawienia (tabeli) wskazującego ustawę, której dotyczy repeal act, oraz zakresu uchylenia (całkowite bądź częściowe). Inną charakterystyczną cechą tego typu ustaw jest ich „dalekosiężność” w wymiarze retrospektywnym. Warto dostrzec, że akty uchylają ustawy (bądź przepisy ustaw) pochodzące również sprzed stuleci (przykładowo brytyjska ustawa uchylająca z 1969 r. derogowała - częściowo lub całkowicie - akty z 1297, 1300 i 1327 r., a także wiele późniejszych, niemniej pochodzących sprzed kilkuset lat). Podobnie (choć z oczywistych względów w węższym zakresie) dzieje się w innych państwach Wspólnoty Narodów - w Indiach na mocy The Repealing and Amending (Second) Act z 2017 r. derogacją objęto akty z okresu 1850-2012 r.; w Nowej Zelandii Statutes Repeal Act z 2017 r. sięgnął do roku 1872. Zauważalna jest nadto „wszechstronność” ustaw uchylających. Ustawy te nie mają jednorodnego tematycznie charakteru, są bowiem budowane na zupełnie innej zasadzie. W tym przypadku o zakresie przedmiotowym aktu decyduje potrzeba „pozbycia się” określonych regulacji z systemu prawa, a nie spójna, całościowa wizja reformy określonego wycinka rzeczywistości prawnej i społecznej. Dla przykładu brytyjski Statute Law (Repeals) Act z 1998 r. dotykał takich dziedzin, jak wymiar sprawiedliwości (Administration of Justice), prawo kanoniczne (Ecclesiastical Law), edukacja, finanse publiczne, akty prawne obowiązujące w Szkocji (Scottish Local Acts), a nawet handel niewolnikami (Slave Trade Acts), a australijski Statute Law Revision Act z 2016 r. odnosił się do takich zagadnień, jak hodowla zwierząt, mleczarstwo i zabezpieczenie społeczne.

32 S.W. STARK, op. cit., s. 43. 
unowocześnienie języka, eliminowanie niespójności ${ }^{33}$. W przeciwieństwie do przedstawionych wyżej czynności „oczyszczających”, konsolidacja odnosi się do spójnych tematycznie obszarów (topics) ${ }^{34}$. Zadania konsolidacyjne są wprost wyartykułowane w aktach ustanawiających komisje w Anglii i Walii, Australii, Bangladeszu, Namibii, Nigerii, Papui Nowej Gwinei, RPA, Sierra Leone, Sri Lance, Tanzanii, Tonga i Wyspach Salomona.

Trzecia grupa zadań jest związana z działaniami na rzecz kodyfikacji prawa. Zadanie tego rodzaju przewidują ustawy ${ }^{35}$, które regulują działanie komisji (m.in. w Anglii i Walii, na Bahamach, Fidżi, w Malawi, w Namibii, Nigerii, Pakistanie, Papui Nowej Gwinei, RPA, Rwandzie i Zambii) ${ }^{36}$. Ustawy nie zawierają bardziej szczegółowych unormowań w tym zakresie, zwłaszcza nie określają, na czym ma polegać kodyfikacja. W praktyce działania komisji przejawiło się zatem zarówno podejście „maksymalistyczne” (zakładające odnoszenie pojęcia kodyfikacji do działań zmierzających do objęcia jedną kompleksową regulacją rozległych dziedzin prawa), jak i „minimalistyczne” (polegające na skupieniu działań kodyfikacyjnych na próbie ujęcia w jednym akcie prawnym skromniejszych zakresowo zagadnień) ${ }^{37}$. Warto w tym miejscu zauwa-

33 Por. The Law Commission and consolidation, https://s3-eu-west-2.amazonaws. com/lawcom-prod-storage-11jsxou24uy7q/uploads/2015/06/The-Law-Commission-and-consolidation.pdf (dostęp: 20 kwietnia 2019 r.).

34 Ibidem. Od 1965 r. komisja prawa Anglii i Walii przygotowała ponad 200 projektów ustaw konsolidacyjnych - por. https://www.lawcom.gov.uk/consolidation/ (dostęp: 20 kwietnia 2019 r.). Od działalności tego typu (prowadzącej do ustanowienia nowego prawa) należy odróżnić rodzajowo inne czynności, polegające na publikowaniu zbiorów ujednoliconych ustaw obowiązujących w danym państwie; zbiory takie nie mają waloru aktów prawnych, niemniej bywają przywoływane w praktyce sądowej (por. Changing the Law. A Practical Guide to Law Reform, http://www.calras.org/pub/ Main/LawReform/Changing\%20The\%20Law.pdf, s. 12; dostęp: 20 kwietnia 2019 r.).

35 Ustawy te czynią to zresztą w zróżnicowany sposób: albo stanowią wprost o obowiązku dokonywania kodyfikacji prawa (tak np. w RPA), albo w sposób bardziej ogólny o przygotowywaniu rekomendacji dotyczących skodyfikowania określonych dziedzin prawa (tak w Malawi).

36 W Zambii komisja prawa ma za zadanie kodyfikować niepisane prawo obowiązujące w tym państwie.

37 Szerzej S.W. Stark, op. cit., s. 154 i n. 
żyć, że kodyfikacja prawa jest jednym z największych wyzwań stojących przed komisjami prawa. Dzieje się tak z uwagi na dwie okoliczności: relatywnie nieduże „moce przerobowe” komisji uwarunkowane niewielką liczebnością i skromnymi zasobami oraz - równocześnie - dużą złożoność zadania kodyfikacyjnego ${ }^{38}$.

Po czwarte, należałoby wspomnieć o wielu przedsięwzięciach, które nie wpisują się całkowicie w powyżej opisany zestaw zadań, ale są wykonywane $z$ uwagi na specyfikę otoczenia normatywnego i społecznego danej komisji prawa. Przykładowo można wymienić niektóre z nich: na Bahamach komisja prawa jest zobowiązana do tego, by nie częściej niż raz na pięć lat przygotowywać zbiór prawa stanowionego, obowiązującego w tym państwie ${ }^{39}$; komisja prawa w Kenii ma za zadanie podejmować działania edukacyjne na rzecz reform prawa; w Malawi komisja ma zajmować się sporządzaniem rekomendacji w zakresie harmonizowania prawa zwyczajowego i innych norm prawnych; w RPA do zadań komisji należy unifikacja prawa obowiązującego w różnych częściach państwa; w Rwandzie komisja prawa ma zapewniać instytucjom publicznym wsparcie w zakresie reform prawnych.

Trzeba wreszcie zwrócić uwagę na szczególny charakter zadań komisji prawa. Otóż mają one charakter niewładczy. Innymi słowy komisje nie posiadają kompetencji, na mocy których mogłyby samodzielnie stanowić prawo. Nie mogą one również oddziaływać wiążąco na inne organy państwa, w szczególności ich inicjatywy o charakterze legislacyjnym (raporty, sprawozdania, propozycje, projekty) nie obligują organów władzy posiadających kompetencje prawodawcze do uwzględniania tychże w swoich działaniach. Wydaje się raczej, że (w braku pozytywnych przesądzeń w tym zakresie) zależności między komisjami a innymi instytucjami, które posiadają kompetencje prawodawcze, są pochodną kultury politycznej i prawnej, a także autorytetu komisji.

38 Dla przykładu - na polu kodyfikacji komisja prawa w Anglii i Walii może wykazać się tylko niewielkimi osiągnięciami - ibidem, s. 187.

39 Na Malcie komisja prawa tego rodzaju zadanie ma wykonywać nie rzadziej niż raz na 10 lat. 


\section{WNIOSKI}

Komisje prawa wrosły w pejzaż ustrojowy państw Wspólnoty Narodów. Są one instrumentami służącymi prowadzeniu systematycznych studiów nad prawem, popartych konkretnymi propozycjami legislacyjnymi, a w rezultacie - wieńczonych modyfikacjami systemu prawa.

Zwraca uwagę powszechność komisji prawa, rozumiana jako atrakcyjność tego rodzaju instytucji dla państw o różnej charakterystyce. Są one obecne w ustroju państw Wspólnoty w Europie, Azji, Afryce oraz w Australii i Oceanii; funkcjonują zarówno w państwach wysoko rozwiniętych, jak i rozwijających się. Mamy z nimi do czynienia w państwach cieszących się długą tradycją ewolucyjnego rozwoju systemu prawa, jak i w tych, które w swej historii przebyły burzliwą drogę rozwojową, częstokroć naznaczoną tragicznymi wydarzeniami. Komisje prawa funkcjonują zarówno w państwach dużych i o złożonej strukturze ustrojowej, jak i w państwach niewielkich ${ }^{40}$.

Co interesujące, komisje prawa występują także poza kręgiem państw Wspólnoty Narodów ${ }^{41}$. Ponadto komisje z kręgu państw Commonwealth współdziałają na poziomie międzynarodowym: instytucje zajmujące się reformą prawa państw członkowskich Wspólnoty Narodów są zrzeszone w organizacji CALRAs (Commonwealth Association of Law Reform Agencies $)^{42}$; jest to organizacja skupiająca formalnie 18 instytucji tego

40 Wskazuje się też na trudności związane $\mathrm{z}$ funkcjonowaniem komisji prawa w niewielkich państwach, zwłaszcza położonych w Oceanii, i dostrzega się możliwość powołania regionalnej komisji prawa - por. T. Seumanutafa, Law Reform in Plural Societies, Cham 2018, s. 21 i n.

${ }^{41}$ Np. w Stanach Zjednoczonych Ameryki, Irlandii, Hong Kongu, Nepalu. Pełen wykaz instytucji tego rodzaju można odnaleźć np. w: S. Then, T. CArney, C. Bigby, J. Douglas, Supporting decision-making of adults with cognitive disabilities: The role of Law Reform Agencies - Recommendations, rationales and influence, "International Journal of Law and Psychiatry» 61/2018, s. 67-69. Autorzy przywołują łącznie 67 komisji prawa lub instytucji o podobnym charakterze (law reform agency). Por. także G. Murphy, Law Reform Agencies, http://bit.ly/zp20-1-3, passim (dostęp: 20 kwietnia 2019 r.).

42 CALRAs powstała w 2003 r., a dwa lata później uzyskała akredytację przy Wspólnocie Narodów. Przynależy zatem do organizacji zaliczanych do „rodziny 
rodzaju ${ }^{43}$. Dodatkowo część z instytucji skupionych w CALRAs jest także stowarzyszona w organizacji ALRAESA (Association of Law Reform Agencies of Eastern and Southern Africa $)^{44}$.

Równocześnie komisje prawa nie mają charakteru jednolitego. Nie istnieje żaden powszechnie przyjęty standard, który byłby automatycznie powielany przy tworzeniu komisji prawa w danym państwie. W tym zakresie prawodawca dysponuje swobodą, umożliwiającą ukształtowanie instytucji w zgodzie zarówno z potrzebami społecznymi, jak i specyfiką danego systemu prawnego. Niemniej warto uwypuklić takie okoliczności związane z funkcjonowaniem komisji prawa, jak: umocowanie ustawowe tych organów, kompleksowe uregulowanie w akcie prawnym poświęconym komisji, względna niezależność od egzekutywy i legislatywy, profesjonalizm członków komisji, szczególne zadania o charakterze reformatorskim, „oczyszczającym” i kodyfikacyjnym.

Aktualny kształt ustrojowy komisji prawa jest wypadkową licznych prób instytucjonalizacji działań reformatorskich, czyli ich profesjonalizacji i osadzenia na trwałej organizacyjnej ramie ${ }^{45}$. Trudno obecnie przesądzić, czy ten kształt jest optymalny i czy w przyszłości nie dojdzie do jego modyfikacji, na przykład zawężenia lub poszerzenia zakresu zadań komisji albo zmiany ich usytuowania w strukturze ustrojowej

Wspólnoty Narodów" (Commonwealth Family), czyli grupy kilkudziesięciu organizacji międzyrządowych, pozarządowych i ruchów społecznych powiązanych z Commonwealth (por. A. Polus, op. cit., s. 292-294; wyliczenie zawarte tamże nie wymienia jednak CALRAs).

43 Chodzi o komisje w: Anglii i Walii, na Jersey, w Lesotho, Malawi, Mauritiusie, Namibii, Nowej Zelandii, Nigerii, Szkocji, RPA, Tanzanii, Trynidadzie i Tobago, Ugandzie, Vanuatu, komisję australijską ze stanu Wiktoria, a nadto trzy instytucje z Kanady - z prowincji Alberta, Kolumbii Brytyjskiej i Manitoba. Z CALRAs współpracują także inne instytucje, nie są one jednak członkami tej organizacji.

44 ALRAESA powstała w 2003 r. Zrzesza Botswanę, Kenię, Lesotho, Malawi, Mauritius, Namibię, Rwandę, Republikę Południowej Afryki, Suazi, Tanzanię, Ugandę, Zambię i Zimbabwe.

45 Instytucjonalizacja reformy prawa jest uważana za pochodzącą z lat 60 . XX w. innowację odnoszącą się do systemu prawa - por. N. REEs, The birth and rebirth of law reform agencies, https://www.lawreform.vic.gov.au/sites/default/files/ ALRAC\%2BPaper\%2B_NeilRees.pdf, s. 16 (dostęp: 20 kwietnia 2019 r.). 
państwa. Wydaje się to zresztą prawdopodobne, wziąwszy pod uwagę, że organizacja państwa nie jest czymś stałym, lecz podlega ciągłemu dostosowywaniu do uwarunkowań o różnorodnym charakterze.

KOMISJE PRAWA W PAŃSTWACH WSPÓLNOTY NARODÓW. ZARYS ZAGADNIEŃ USTROJOWYCH

\section{Streszczenie}

Artykuł przedstawia zarys zasad funkcjonowania komisji prawa w państwach Wspólnoty Narodów. Komisje są instytucjami, które działają na rzecz systematycznej reformy prawa, obejmującej cały system prawny państwa.

Opracowanie koncentruje się na zagadnieniach systemowych, takich jak sposób ustanawiania komisji, niezależność komisji i zakres powierzonych zadań. Artykuł przedstawia sposób, w jaki komisje są unormowane w aktach prawnych, oraz omawia takie zagadnienia, jak ich niezależność, przejawiająca się w oddzieleniu od innych władz, a także skład komisji, gwarantujący jej wysoki poziom intelektualny i profesjonalizm. Wśród zadań komisji wyróżniono: dokonywanie systematycznego przeglądu aktów prawnych, proponowanie zmian w poszczególnych obszarach prawa, uchylanie zbędnych i przestarzałych przepisów z systemu prawnego, jak również konsolidację i kodyfikację prawa.

\section{Law Commissions in the Commonwealth Countries: An OutLine of Constitutional Issues}

\section{Summary}

The article presents an outline of the principles for the operations of the law commissions in the Commonwealth countries. Law commissions are institutions which work for systematic law reform, encompassing a country's entire legal system.

The article concentrates on systemic issues, such as the institution of commissions, the independence of the commissions, and the scope 
of the tasks assigned to them. The study shows how the commissions are regulated on the grounds of legislation, and discusses issues such as their independence, which is manifested in their separation from other authorities, in particular from the legislative and executive authorities. The article continues with a discussion of the appointment of their members, who are required to prove their intellectual and professional qualifications. The tasks of the commissions discussed in this article are their duties to conduct a systematic review of legislation, to propose changes in specific areas of the law, to repeal unnecessary and obsolete provisions, and to consolidate and codify the law of their country.

Słowa kluczowe: komisja prawa; reforma prawa; Wspólnota Narodów. Keywords: law commission; law reform; The Commonwealth.

\section{Literatura}

Arden M., Law and Law Reform: Are We Ready for the Twenty-First Century?, «The Liverpool Law Review» 20.2/1998, s. 163-176.

BARnes J., On the ground and tap-law reform, Australian style, «The Theory and Practice of Legislation» 6.2/2018, s. 193-224.

Kinвy M., Forty years of the Alberta Law Reform Institute - past, present, future, «Alberta Law Review» 46.3/2009, s. 831-845.

Moore M., The past, present and future of law reform in Canada, «The Theory and Practice of Legislation» 6.2/2018, s. 225-261.

Murphy G., Law Reform Agencies, http://justice.gc.ca/eng/rp-pr/csj-sjc/ilp-pji/ lr-rd/lr-rd.pdf (dostęp: 20 kwietnia 2019 r.).

Partington M., Law Reform: The UK Experience, [w:] Reforming Law Reform. Perspectives from Hong Kong and Beyond, red. L. NG, M. Tilbury, S. Young, Hong Kong 2014, s. 67-86.

Polus A., Commonwealth na arenie międzynarodowej, Wrocław 2009.

ReEs N., The birth and rebirth of law reform agencies, https://www.lawreform. vic.gov.au/sites/default/files/ALRAC\%2BPaper\%2B_NeilRees.pdf (dostęp: 20 kwietnia 2019 r.).

Seumanutafa T., Law Reform in Plural Societies, Cham 2018.

Stark S.W., The Work of the British Law Commissions. Law Reform... Now?, Oxford-Portland 2017.

StARZEWski M., Ustrój dominionów i charakter Brytyjskiej Rzeczpospolitej Narodów, Kraków 1939. 
Then S., Carney T., Bigby C., Douglas J., Supporting decision-making of adults with cognitive disabilities: The role of Law Reform Agencies - Recommendations, rationales and influence, "International Journal of Law and Psychiatry» 61/2018, s. 64-75.

WARNER K., Lessons from a Small University-based Law Reform Body in Australia, [w:] Reforming Law Reform. Perspectives from Hong Kong and Beyond, red. L. Ng, M. Tilbury, S. Young, Hong Kong 2014, s. 113-132. 